\title{
Tavuk Dışkıları ve Çevresel Örneklerden Salmonella Infantis Fajlarının İzolasyonu ve Karakterizasyonu
}

\author{
Ebru Torun ${ }^{1}$, Hamit Kaan Müştak ${ }^{1}$ \\ ${ }^{1}$ Ankara Üniversitesi Veteriner Fakültesi Mikrobiyoloji Anabilim Dall, Ankara, Türkiye
}

Geliş Tarihi / Received: 21.10.2019, Kabul Tarihi / Accepted: 09.12.2019

\begin{abstract}
Özet: Bu çalışmada, Türkiye'de en çok izole edilen kanatlı Salmonella serotipi olan S. Infantis bakteriyofajlarının izolasyonu ve bu fajların konak spektrumunun belirlenmesi ayrıca bu fajların su, yem ve altlık materyallerindeki etki ve yaşam süreleri ile saklama sürelerinin belirlenmesi amaçlandı. Çalışmada, 50 adet dışkı-altlık ve 50 adet atık su örneğinden izole edilen 38 adet $S$. Infantis fajının, rutin test dilüsyonları, litik spektrumları ve litik profilleri belirlenerek seçilen fajlar RAPD-PCR ile genotiplendirildi. Litik profilleri ve RAPD homoloji düzeyleri birbirinden farklı olanlar arasından seçilen en yüksek litik spektruma sahip fajların (SF-In7, SF-In20) faj-bakteri dinamikleri incelendi. SF-In7, SF-In20 fajlarının adsorbsiyon oranı $20 \mathrm{dk}$ ' da $\% 95$ ve latent dönemleri ise sırasıyla $57 \mathrm{dk}$ ve $65 \mathrm{dk}$ olarak belirlendi. Deneysel çalışmalarda SF-In7 ve SF-In20 fajlarının 24 saatte canlı $S$. Infantis sayısını su materyalinde $4 \log _{10} \mathrm{cfu} / \mathrm{ml}(\mathrm{p}<0,001)$, altlık ve yem materyalinde 2-3 $\log _{10} \mathrm{cfu} / \mathrm{ml}(\mathrm{p}<0,001)$ azalttığı, konak hücre bulundurmayan su materyalinde 4 hafta, altlık ve yem materyallerinde ise 3 hafta yaşadı ̆̆ı tespit edildi. Ayrıca çalışmada, SF-In7 ve SF-In20 fajlarının oda ısında $\left(20-22^{\circ} \mathrm{C}\right) 6$ hafta, $4^{\circ} \mathrm{C}^{\prime} \mathrm{de} 9$ ay, $-20^{\circ} \mathrm{C}$ ve $-80^{\circ} \mathrm{C}^{\prime}$ de ise 4 yıldan fazla canlılıklarını korudukları belirlendi. Çalışma sonucunda, SF-In7 ve SF-In20 fajlarının $S$. Infantis kontaminasyonunu azaltmada biyokontrol ajanı olarak kullanılabileceği, geniş saklama 1sısı ve uzun yaşam süresi sebebiyle saha, kümes, kesimhane gibi ortamlarda uygulanmadan önce uzun süre kolaylıkla saklanabileceği sonucuna varıldı.
\end{abstract}

Anahtar kelimeler: Bakteriyofaj, biyokontrol, tavuk, Salmonella Infantis.

\section{Isolation and Characterization of Salmonella Infantis Phages from Poultry Faces and Environmental Samples}

\begin{abstract}
In this study, it was aimed to isolate the bacteriophages of $S$. Infantis, the most isolated Salmonella serotype of poultry in Turkey, to determine the effect and lifespan in the water, litter and feed and to detect the host spectrum and the storage time of these phages. In this study, the routine test dilutions, lytic spectra and lytic profiles of $38 \mathrm{~S}$. Infantis phages isolated from 50 stool-litter and 50 wastewater samples were determined and the selected phages were genotyped by RAPD-PCR. Phage-bacterial dynamics of phages with the highest litic spectrum (SF-In7, SF-In20) selected among the different litic profiles and RAPD homology levels were investigated. The adsorption rate of SF-In7, SF-In20 phages was determined as $95 \%$ in 20 min and latency periods were determined as 57 min and 65 min, respectively. In experimental studies, it was determined that the SF-In7 and SF-In20 phages decreased the number of alive $S$. Infantis in $24 \mathrm{~h}$ at $4 \log _{10} \mathrm{cfu} / \mathrm{ml}(\mathrm{p}<0.001)$ in water and at $2-3 \log _{10} \mathrm{cfu} / \mathrm{ml}(\mathrm{p}<0.001)$ in feed and litter and found to be alive for 4 weeks in the water and 3 weeks in the feed and litter without host cells. In addition, it was also determined that the SFIn 7 and SF-In 20 phages survived for 6 weeks at room temperature $\left(20-22^{\circ} \mathrm{C}\right), 9$ months at $4{ }^{\circ} \mathrm{C}$, and more than 4 years at $-20^{\circ} \mathrm{C}$ and $-80^{\circ} \mathrm{C}$. As a result of the study, SF-In 7 and SF-In 20 phages can be used as biocontrol agents to reduce the $S$. Infantis contamination, and can be stored easily for a longtime period before application in environments such as field, poultry house, slaughterhouse due to its large storage temperature and long life span.
\end{abstract}

Key words: Bacteriophage, biocontrol, chicken, Salmonella Infantis.

\section{Giriş}

Salmonella enfeksiyonları tüm dünyada ve Türkiye'de kanatlı endüstrisinin en önemli problemlerinden birisidir (Aksakal, 2003). Ayrıca kanatlı hayvanlardan insanlara gida kaynaklı bulaşarak zoonotik enfeksiyonlara neden olması sebebiyle halk sağlığı açısından da oldukça önemlidir (Sengül ve
Türkyılmaz, 2007; EFSA 2016). Salmonella genusu içerisinde yer alan yaklaşık 2700 serotip içerisinde insanlarda Salmonellozise neden olan en yaygin serotipler $S$. Enteritidis ve $S$. Typhimurium olarak bilinmektedir. Ancak son yıllarda başta $S$. Infantis olmak üzere diğer serotiplerin izolasyon oranlarının arttığ 1 gözlenmektedir (Miller ve ark. 2010). European Food Safety Authority (EFSA)'nın son 
raporunda (EFSA, 2017), S. Infantis'in insanlarda en yaygın dördüncü serotip olduğu, bununla beraber son beş yılda tavuklarda en yaygın görülen serotipin $S$. Infantis $(\% 33,6)$ olduğu ve bunu $S$. Enteritidis $(\% 15,8)$ ve $S$. Mbandaka $(\% 6,7)$ 'nın izlediği bildirilmiştir. Türkiye' de yapılan çalışmalarda ise tavuklardan izole edilen en yaygin serotipin $S$. Infantis olduğu belirlenmiştir (Anonim 2018).

Bakteriyofajların insanlarda tedavi amaciyla kullanımı uzun yıllardan beri bilinmektedir. Özellikle Salmonella'larda antibiyotiklere karşı gelişen dirençle beraber kanatlı Salmonellozis'inin önlenmesi ve tedavi edilmesi için de alternatif olarak faj çalışmaları bulunmaktadır. Salmonella fajları, kanatlı dışkıları ve kanatlı çiftlikleri çevresinden kolaylıkla izole edilebilmekte ve kanatlı üretiminden başlayarak kümes uygulamaları (yem, altlık, su, yüzey gibi materyaller), hayvanlarda kolonizasyonu önlemek veya azaltmak için hayvan uygulamaları, ya da gida uygulamalarında kullanılabilmektedir. Salmonella fajları ile Salmonella kolonizasyonunun tavuklarda azaltılması (Atterbury ve ark. 2007; Borie ve ark. 2008; Bardina ve ark. 2012) üzerine ve insanlara Salmonella geçişini azaltmak amacıyla gıda maddelerinde ve gida hazırlama bölgelerin de Salmonella kontaminasyonunun önlenmesi ve azaltılması üzerine birçok çalışma mevcuttur (Spricigo ve ark. 2013; Woolston ve ark. 2013; Huang ve ark. 2018). Bu çalışmalar genellikle en yaygın serotipler olan $S$. Enteritidis ve $S$. Typhimurium serotipleri kullanılarak yapılmıştır. Ancak çalışmalarda $S$. Infantis serotipi kullanılarak faj izolasyonun ve karakterizasyonunun yapıldığ su, altlık ve yem materyallerinde in vitro olarak $S$. Infantis fajlarının etkinliğinin araştırıldığı çalışmalar bulunmamaktadir.

Bu çalışmada, Türkiye'de en çok izole edilen kanatl1 Salmonella serotipi olan $S$. Infantis'in bakteriyofajlarının izolasyonu ve bu fajların konak spektrumlarının belirlenmesi, ayrica izolasyonu yapilan ve konak aralığı belirlenen bu fajların etki, yaşam ve saklama sürelerinin saptanması amaçlandı.

\section{Gereç ve Yöntem}

\section{Bakteri Suşları ve Kontrol Fajı}

Salmonella Infantis suşları, Ankara Üniversitesi Veteriner Fakültesi Mikrobiyoloji Anabilim Dalı kültür koleksiyonundan temin edildi. Konak hücreleri olarak lizojenik faj bulundurmadığ 1 bilinen kanatlı orijinli 10 adet $S$. Infantis suşu, fajların litik spektrumlarını belirlemek amaciyla ise kanatlı orijinli 200 adet $S$. Infantis suşu kullanıldı. Kontrol amacıyla çalışmanın tüm aşamalarında Gürcistan ELIAVA Enstitüsü'nden temin edilen $S$. Enteritidis vB-GES-Se-K1 Tiflis Fajı kullanıldı.

\section{Bakteriyofaj İzolasyon Materyali}

İzolasyon için, Ankara ve Bolu illerinde yer alan kanatl işletmelerinden toplanan 50 adet dişk1-altlık örneği ve kanatlı kesimhanelerine ait arıtma tesislerinden toplanan 50 adet atık su örneği olmak üzere toplam 100 örnek kullanıld1.

\section{Bakteriyofajların İzolasyonu ve Çoğaltılması}

Tavuk dışkı-altlık örnekleri 1/10 oranında Luria Bertani broth (Neogen, USA) ile sulandirılıp homojenize edilerek, atık sular ise direkt olarak santrifüj edildikten sonra 0,2 $\mu$ m'lik filtrelerden (Sartorius, Germany) geçirildi, filtratlar ayrıldı ve faj kaynağ1 olarak kullanıldı. Filtratlar $10 \mathrm{ml}$ çift katlı LB broth içerisine besi yeri ile eşit miktarda alındı ve $S$. Infantis suşunun 4-6 saatlik logaritmik fazdaki kültüründen $500 \mu \mathrm{l}$ eklenerek $37^{\circ} \mathrm{C}$ 'de $50 \mathrm{rpm}$ 'de 24 saat inkübe edildi. İnkübasyon sonucunda 7000 rpm'de $20 \mathrm{dk}$ santrifüj edildi ve süpernatant 0.2 $\mu \mathrm{m}$ filtreden geçirildi. Filtratlardaki litik aktivitenin belirlenmesi amaciyla spot test uygulandi. Kullanılan $S$. Infantis suşunun logaritmik fazdaki sıv1 kültüründen dip katı agara (LB Broth $20 \mathrm{~g} / \mathrm{L}$, Bakteriyolojik Agar $15 \mathrm{~g} / \mathrm{L}) 100 \mu \mathrm{l}$ yayma ekim metodu ile ekildi ve üzerine $10 \mu \mathrm{l}$ faj filtratı damlatılarak $37^{\circ} \mathrm{C}$ 'de 24 saat inkübasyona birakıldı. Litik faj aktivitesi görülmeyen filtratlar atıldı, görülen filtratlar ise agar-overlay yöntemi ile saflaştırıldı (Carey-Smith ve ark. 2006; Kutter, 2009; Bao ve ark. 2011). Saflaştırılan fajlar agarın üzerine dökülen SM (Saline-Magnesium, faj tamponu: 5,8 g/L $\mathrm{NaCl}, 2 \mathrm{~g} / \mathrm{L} \mathrm{MgSO}_{4} 7 \mathrm{H}_{2} \mathrm{O}, 50 \mathrm{ml} / \mathrm{L} 1 \mathrm{M}$ Tris- $\mathrm{HCl}$, $5 \mathrm{ml} / \mathrm{L} \% 2$ 'lik Jelatin solüsyonu) solüsyonu ile bir gece $37^{\circ} \mathrm{C}$ 'de 50 rpm'de inkübe edildikten sonra topland. Toplanan süspansiyon $7000 \mathrm{rpm}$ 'de $10 \mathrm{dk}$ santrifüj edilerek, üst sıvı $0.2 \mu \mathrm{m}$ filtreden geçirildi. Elde edilen fajlar içerisine 1-2 damla kloroform eklenerek $-80^{\circ} \mathrm{C}$ 'de saklandi. 


\section{Rutin Test Dilüsyonunun Belirlenmesi}

Rutin Test Dilüsyonu (RTD)'nu belirlemek için agar-overlay yöntemi kullanıld1. $\mathrm{Bu}$ amaçla $10^{6}$ $\mathrm{cfu} / \mathrm{ml} S$. Infantis suşunun ekildiği agar üzerine her bir faj stoğunun ayr1 ayrı LB broth ile hazırlanan $10^{-1}-10^{-12}$ arasında 10 katlı dilüsyonlarından ayrı ayrı işaretlenen yere $10 \mu \mathrm{l}$ damlatıld $1.37^{\circ} \mathrm{C}$ 'de 18 24 saat inkübasyon sonrasında plak formasyonları okundu ve stok faj süspansiyonundaki faj sayısı mililitredeki plak oluşturan ünite $(\mathrm{pfu} / \mathrm{ml})$ cinsinden hesapland1 (Kropinski ve ark. 2009).

\section{Fajların Litik Spektrumlarının ve Litik Profillerinin Belirlenmesi}

Elde edilen $S$. Infantis fajlarından, RTD $1 \times 10^{4}$ 'ün üzerinde olanların her birinin 200 adet $S$. Infantis suşundaki litik spektrumları spot test yöntemi ile belirlendi. Bu amaçla, logaritmik fazdaki $S$. Infantis suşları $100 \mu \mathrm{l}$ dip agar üzerine yayma ekim yöntemi ile ekildi. Rutin test dilüsyonu $10^{4}-10^{9} \mathrm{pfu} /$ $\mathrm{ml}$ olan fajlar, işaretlenmiş yerlere $10 \mu \mathrm{l}$ damlatıld1 ve $37^{\circ} \mathrm{C}$ 'de $18-24$ saat inkübasyona birak1ld1. İnkübasyon sonucunda faj plaklarının oluşup oluşmamasına göre fajların litik spektrumu değerlendirildi (Carey-Smith ve ark. 2006; Kutter, 2009; Bao ve ark. 2011). Fajların litik profillerinin belirlenmesi amacıyla ise ilk önce suşlar numaralandırıldı ve her bir fajın hangi $S$. Infantis suşunu lize ettiği kaydedildi. Aynı suşları lize eden fajlar benzer litik profilde kabul edildi. Litik profilleri en fazla lize edilen suş sayısına göre numaralandırıldı (Cortes ve ark. 2015).

\section{Rastgele Çoğaltılmış Polimorfik DNA-PCR Analizi}

Farklı litik profile sahip fajlar arasında, $\% 90$ ve üstü litik spektruma sahip fajların tamamının faj DNA izolasyonu, Norgen Faj DNA İzolasyon Kiti (Norgen Biotek, Kanada) ile kitin protokolüne göre gerçekleştirildi. Polimorfik DNA'nın rastgele çoğaltılması için RAPD PCR analizi Cortes ve ark. (2015) ile Gutierrez ve ark. (2011)'nın bildirdikleri yönteme göre gerçekleştirildi. Amplifikasyon amacıyla Cortes ve ark. (2015) ile Gutierrez ve ark. (2011)'nın çalışmalarında önerdikleri ve en fazla RAPD paternini oluşturan P1 (5'-CCGCAGCCAA-3') primeri kullanıld1.

\section{Faj-Bakteri Dinamikleri}

İzolasyonu yapılan fajlardan, RTD $10^{-4}$ 'ün üzerinde olup, $\% 90$ ve üstü litik spektruma sahip, litik profilleri ve RAPD PCR paternleri birbirinden farkl olan fajlar ve bu fajların konak $S$. Infantis suşu seçilerek bütün faj-bakteri dinamiklerinin belirlenmesi çalışmalarında kullanıldı. Minimal faj ve minimal bakteri sayısının belirlenmesi amacıyla Wiggins ve Alexander (1985)'ın yöntemi; faj adsorbsiyon oranının belirlenmesi için ise Sanders ve Klaenhammer (1980)'in bildirdiği yöntem kullanıldı. Faj adsorbsiyon oranı zamana karşı pfu' daki azalma oranı olarak ifade edildi. Hyman ve Abedon (2009)'un bildirdiği yönteme göre faj latent süreleri $0,30,45$ ve $45 \mathrm{dk}$ sonra birer dakikalık periyotlarda agar overlay yöntemi ile faj sayımı yapılarak kontrol edildi.

\section{Faj Etkinliğinin Saptanması}

Bu aşamaya kadar bütün özellikleri araştırılan fajın etkinliği kendi konağı olan $S$. Infantis suşu kullanılarak su, altlık ve yem materyallerinde test edildi. $\mathrm{Bu}$ amaçla, Salmonella spp. yönünden negatif ve laboratuvar koşullarında $10^{6} \mathrm{cfu} / \mathrm{ml}$ yoğunluktaki $S$. Infantis ile deneysel olarak inoküle edilmiş $9 \mathrm{ml}$ su, $10 \mathrm{~g}$ altlık ve $10 \mathrm{~g}$ yem materyali her bir faj ve her saat için ayrı ayrı kullanıldı. Bu materyallere $10^{9}$ $\mathrm{pfu} / \mathrm{ml}$ yoğunluktaki fajdan $1 \mathrm{ml}$ uygulanarak canlı bakteri sayısı üzerindeki etkisi ve etki süresi (1 h, 12 h ve 24 h) agar overlay yöntemi ile incelendi.

\section{Faj Yaşam Süresinin Saptanması}

$\mathrm{Bu}$ amaçla, Salmonella spp. yönünden negatif olduğu belirlenen $9 \mathrm{ml} \mathrm{su}, 10 \mathrm{~g}$ altlık ve $10 \mathrm{~g}$ yem materyali her bir faj örneği ve her saat için ayrı ayrı kullanıldı. Bu materyallere $10^{9} \mathrm{pfu} / \mathrm{ml}$ yoğunluktaki fajdan $1 \mathrm{ml}$ uygulanarak yaşam süresi incelendi. Uygulama yapılan materyallerden bir hafta süreyle, her gün ve her hafta örnekler alınarak faj aktivitesinin korunup korunmadığı ve pfu sayısı agar-overlay yöntemi ile incelendi.

\section{Faj Saklama Süresinin Saptanması}

Bu amaçla, RTD'nu $1 \times 10^{9}$ olan fajlar arasından seçilen fajlar SM solüsyonuna toplandıktan sonra ikişer $\mathrm{ml}$ tüplere alındı. Tüpler oda $1 \mathrm{~s} 1 \mathrm{~s} 1,+4^{\circ} \mathrm{C},-20^{\circ} \mathrm{C}$ ve $-80^{\circ} \mathrm{C}$ 'de bekletildi. Bu preparatlardan gittikçe artan zaman aralılarında (ilk hafta her gün, ilk ay 
her hafta ve daha sonra aylık ve yıllık aralıklarla) örnekler alınarak faj aktivitesi ve sayısı agar-overlay yöntemi ile incelendi.

\section{İstatistiksel Analiz}

Fajların etkinliği, 24 saat sonunda, faj uygulaması yapılmayan su, altlik ve yem örneklerindeki canlı $S$. Infantis sayısının, fajlar ile muamele edilmiş su, altlik ve yem örneklerindeki canlı $S$. Infantis say1s1 ile karşılaştırılarak değerlendirildi. Farklılıkların istatistiksel olarak anlamlı olup olmadığını belirlemek için Ki-Kare analizi kullanıldı, $\mathrm{p}<0.05$ anlamlı kabul edildi (Field, 2009).

\section{Bulgular}

\section{Bakteriyofaj İzolasyonu Bulguları}

Toplanan 50 adet dışkı-altlık örneğinin 26 tanesinde faj aktivitesi belirlenirken sadece 18 adet faj saf olarak izole edildi. Toplanan 50 adet atık su örneğinin 29 tanesinde faj aktivitesi belirlendi ve 20 adet faj saf olarak izole edildi (Tablo 1).

Tablo 1. Kaynağına göre izole edilen toplam faj sayısı.

\begin{tabular}{lccc}
\hline & $\begin{array}{c}\text { Örnek } \\
\text { sayısı }\end{array}$ & $\begin{array}{c}\text { Faj Aktivitesi } \\
\text { Spot test (\%) }\end{array}$ & $\begin{array}{c}\text { Faj İzolasyonu } \\
\text { Agar-Overlay } \\
(\%)\end{array}$ \\
\hline Altık-Dışk1 & 50 & $26(52)$ & $18(36)$ \\
Atık Su & 50 & $29(58)$ & $20(40)$ \\
Toplam & 100 & $55(55)$ & $38(38)$ \\
\hline
\end{tabular}

\section{Rutin Test Dilüsyonu Bulguları}

Toplam 38 fajdan 17 fajın RTD'u 10'ün altında bulundu. Pasaj yapılarak konsantrasyonları arttırılamayan bu 17 adet faj daha sonraki aşamalarda kullanılmadı. RTD değeri $10^{5}$ ve üstünde bulunan 21 fajın RTD değerleri Tablo 2'de verilmiştir.

\section{Fajların Litik Spektrumları ve Litik Profilleri}

RTD $1 \times 10^{4}$ 'ün üzerinde olan 21 fajın 17 farklı litik profile sahip olduğu, litik spektrumlarına göre ise SF-In22 fajinın en dar (\%69.5), SF-In7 fajinın ise en geniş (\%94.5) spektruma sahip olduğu belirlendi (Tablo 2).
Tablo 2. 21 adet $S$. Infantis fajının kaynak, RTD, litik spektrumu ve litik profil verileri.

\begin{tabular}{|c|c|c|c|c|}
\hline Faj & Kaynak & RTD & $\begin{array}{l}\text { Litik } \\
\text { Profil } \\
\end{array}$ & $\begin{array}{c}\text { Litik Etki Görülen } \\
\text { Suş Sayısı (\%) } \\
\end{array}$ \\
\hline SF-In1 & D1şk1-altlık & $3 \times 10^{8}$ & 8 & $177(88.5)$ \\
\hline SF-In3 & Atık Su & $2 \times 10^{9}$ & 13 & $169(84.5)$ \\
\hline SF-In4 & Dışkı-altlık & $3 \times 10^{9}$ & 15 & $153(76.5)$ \\
\hline SF-In7 & Dışk1-altlık & $2 \times 10^{9}$ & 1 & $189(94.5)$ \\
\hline SF-In8 & Dışkı-altlık & $4 \times 10^{5}$ & 7 & $178(89.0)$ \\
\hline SF-In10 & Dışk1-altlık & $3 \times 10^{5}$ & 12 & $172(86.0)$ \\
\hline SF-In12 & Atık Su & $2 \times 10^{9}$ & 10 & $175(87.5)$ \\
\hline SF-In16 & Atık Su & $2 \times 10^{7}$ & 14 & $167(83.5)$ \\
\hline SF-In18 & Dışk1-altlık & $3 \times 10^{5}$ & 5 & $182(91.0)$ \\
\hline SF-In20 & Atık Su & $2 \times 10^{9}$ & 2 & $188(94.0)$ \\
\hline SF-In21 & Atık Su & $4 \times 10^{7}$ & 9 & $176(88.0)$ \\
\hline SF-In22 & Atık Su & $2 \times 10^{6}$ & 17 & $139(69.5)$ \\
\hline SF-In24 & Atık Su & $3 \times 10^{5}$ & 10 & $175(87.5)$ \\
\hline SF-In26 & Atık Su & $3 \times 10^{8}$ & 11 & $172(86.0)$ \\
\hline SF-In27 & Atık Su & $2 \times 10^{5}$ & 16 & $149(74.5)$ \\
\hline SF- In 28 & Dışk1-altlık & $3 \times 10^{8}$ & 12 & $172(86.0)$ \\
\hline SF- In31 & Dışkı-altlık & $2 \times 10^{6}$ & 6 & $179(89.5)$ \\
\hline SF- In33 & Dışk1-altlık & $3 \times 10^{9}$ & 7 & $178(89.0)$ \\
\hline SF- In35 & Atık Su & $3 \times 10^{9}$ & 4 & $184(92.0)$ \\
\hline SF- In37 & Atık Su & $2 \times 10^{7}$ & 3 & $186(93.0)$ \\
\hline SF- In38 & Atık Su & $2 \times 10^{7}$ & 11 & $172(86.0)$ \\
\hline
\end{tabular}

\section{RAPD-PCR Analizi Bulguları}

Litik profilleri farklı fajlar içinden litik spektrumları geniş $(\geq \% 90)$ olduğu belirlenen toplamda 5 adet $S$. Infantis faj1 (SF-In7, SF-In18, SF-In20, SFIn35, SF-In37) RAPD-PCR ile moleküler tiplendirme amacıyla seçildi. RAPD-PCR sonucu en az bir polimorfik bant görülmesi ile fajlar farklı olarak değerlendirildi. RAPD-PCR sonucunda SF-In35, SF-In37 fajlarının benzer paterne sahip olduğu, SFIn7, SF-In18, SF-In20 fajlarının ise birbirinden ve SF-In35, SF-In37 fajlarından farklı olduğu belirlendi. Bu sonuçlara göre 5 adet $S$. Infantis fajı arasından, homoloji düzeyleri birbirinden farklı olup en yüksek litik spektruma sahip olan SF-In7 (\%94.5), SF-In20 (\%94.0) fajları, faj-bakteri dinamikleri ve deneysel çalışmalarda kullanılmak üzere seçildi. 


\section{Faj-Bakteri Dinamikleri Bulguları}

Faj enfeksiyonu için gerekli minimal $S$. Infantis ve minimal faj sayıları sırasıyla SF-In7 için $8.2 \times 10^{4}$ $\mathrm{cfu} / \mathrm{ml}$ ve $5.8 \times 10^{4} \mathrm{pfu} / \mathrm{ml}$; SF-In20 için ise $7.4 \times 10^{4}$ $\mathrm{cfu} / \mathrm{ml}$ ve $6.6 \times 10^{4} \mathrm{pfu} / \mathrm{ml}$ olarak belirlendi. Bununla birlikte, SF-In7 fajlarının \%96'sının, SF-In20 fajlarının ise \%95'nin $20 \mathrm{dk}$ içerisinde konak hücrelerine adsorbe olduğu tespit edildi. Konak $S$. Infantis suşu için SF-In7'nin latent süresinin 57 dk, SF-In20'nin latent süresinin ise $65 \mathrm{dk}$ olduğu belirlendi.

\section{Faj Etkinliğinin Saptanması Bulguları}

Test edilen her iki faj için su, altlık ve yem materyallerinde ilk saat canlı bakteri sayısında herhangi bir değişim görülmedi. Tüm materyallerde canlı bakteri sayısındaki logaritmik azalma, 12 ve 24 'üncü saatler için Tablo 3'de gösterildi. Her üç materyal için de 24'üncü saatte belirlenen logaritmik azalma anlamli bulundu $(\mathrm{p}<0.001)$.

Tablo 3. Test edilen fajların 12 ve 24 'üncü saatlerde neden oldukları canlı bakteri sayısındaki logaritmik $\left(\log _{10}\right)$ azalma (cfu/ml).

\begin{tabular}{lcccccc}
\hline \multirow{2}{*}{ Faj } & \multicolumn{2}{c}{ Su materyali } & \multicolumn{2}{c}{ Altlık materyali } & \multicolumn{2}{c}{ Yem materyali } \\
\cline { 2 - 7 } & 12 saat & 24 saat & 12 saat & 24 saat & 12 saat & 24 saat \\
\hline Kontrol & $\mathrm{P}^{*}$ & $\mathrm{P}$ & $\mathrm{P}$ & $\mathrm{P}$ & $\mathrm{P}$ & $\mathrm{P}$ \\
SF-In7 & & & & $2 \log _{10}$ & $2 \log _{10}$ & $3 \log _{10}$ \\
SF-In20 & $3 \log _{10}$ & $4 \log _{10}$ & $1 \log _{10}$ & $3 \log _{10}$ & & \\
\hline
\end{tabular}

*P, canlı hücre sayısında azalma görülmedi.

\section{Fajların Yaşam Süresinin Saptanması Bulguları}

Günlük ölçümlerin yapıldığı bir hafta içinde su, altl1k ve yem materyallerinde SF-In7 ve SF-In20 fajları, titrelerindeki azalmaya rağmen infektivitelerini devam ettirdikleri tespit edildi. Test edilen tüm materyallerde bir hafta içerisindeki faj titrelerindeki logaritmik azalma ve yaşam süreleri Tablo 4'de gösterilmiştir.

Tablo 4. Fajların titrelerindeki logaritmik $\left(\log _{10}\right)$ azalma (pfu/ml ) ve yaşam süreleri.

\begin{tabular}{|c|c|c|c|c|c|c|}
\hline \multirow[b]{2}{*}{ Faj } & \multicolumn{2}{|c|}{ Su materyali } & \multicolumn{2}{|c|}{ Altlık materyali } & \multicolumn{2}{|c|}{ Yem materyali } \\
\hline & $\begin{array}{l}\text { 1'nci } \\
\text { hafta }\end{array}$ & $\begin{array}{l}\text { Yaşam } \\
\text { süresi }\end{array}$ & $\begin{array}{l}\text { 1'nci } \\
\text { hafta }\end{array}$ & $\begin{array}{l}\text { Yaşam } \\
\text { süresi }\end{array}$ & $\begin{array}{l}\text { 1'nci } \\
\text { hafta }\end{array}$ & $\begin{array}{l}\text { Yaşam } \\
\text { süresi }\end{array}$ \\
\hline $\begin{array}{l}\text { SF-In7 } \\
\text { SF-In20 }\end{array}$ & $2 \log _{10}$ & 4 Hafta & $3.5 \log _{1}$ & 3 Hafta & $3.5 \log$ & 3 Hafta \\
\hline
\end{tabular}

\section{Fajların Saklama Süresinin Saptanması Bulguları}

Ölçümler 2014-2018 yılları arasında yapıldı. Her iki fajın da artan zaman aralıklarında yapılan ölçümlere göre, oda $151 s 1\left(20-22^{\circ} \mathrm{C}\right),+4^{\circ} \mathrm{C},-20^{\circ} \mathrm{C}$ ve $-80^{\circ} \mathrm{C}^{\prime}$ deki titrelerinin değişmeden kaldığ 1 süreler ve toplam yaşam süreleri Tablo 5'de gösterilmiştir.

Tablo 5. Fajların farklı 1sılardaki yaşam süreleri ve titrelerinin değişmeden kaldığ 1 süre.

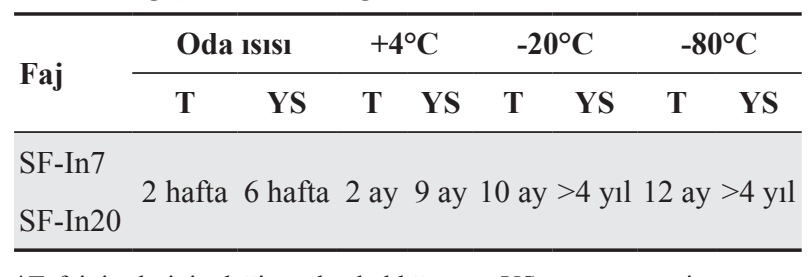

*T, faj titrelerinin değişmeden kaldığı süre; YS, yaşam süresi.

\section{Tartışma ve Sonuç}

Salmonella fajlarının izolasyonunda, dışk1-altlık materyalleri ve kanalizasyon suyu en sik kullanılan materyallerdir (Akhtar ve ark. 2014; Huang ve ark. 2018). Bu sebeple bu çalışmada, dışk1-altlık ve atık su örnekleri faj izolasyon materyali olarak belirlendi. Çeşitli çalışmalarda, kullanılan materyallerden Salmonella faj izolasyon oranları incelediğinde farkl1 veriler mevcuttur. Bardina ve ark. (2012)'nın $S$. Typhimurium'u konak hücre olarak kullandıklar1 çalışmada toplam 189 dışkı örneğinden 55 adet Salmonella faj1 $(\% 29,1)$, Borrie ve ark. (2008), S. Enteritidis'i konak hücre olarak kullandıkları çalışmalarında ise 57 adet atı su materyalinden toplam 8 litik Salmonella $(\% 14,03)$ fajı izole edilmiştir. Salmonella Infantis'in konak hücre olarak kullanıldığ 1 bu çalışmada ise incelenen 50 atık su ve 50 altlık-dışk 1 materyalinden toplam 38 adet $S$. Infantis (\%38) faj1 saf olarak izole edildi. İzolasyon oranları karşılaştırıldığında bu oran Bardina ve ark. (2012) ve Borrie ve ark. (2008)'nın çalışmalarından farklı olarak daha yüksektir. Bu farklılığın, çalışmalarda kullanılan konak hücre serotipinden kaynaklandığı, $S$. Infantis'in bu çalışmada konak olarak seçilmesinin, faj izolasyon şansını ve oranını artırdığı düşünüldü.

Birçok çalışmada izolasyonu yapılan fajların litik spektrumları belirlenmiş ve kullanılacak fajlar en geniş spektruma sahip olmasına göre seçilmiştir (Atterbury ve ark. 2007; Bao ve ark. 2011; Huang 
ve ark. 2018). Bu çalıșmada, RTD $1 \times 10^{4}$ 'ün üzerinde olan $21 S$. Infantis fajının her birinin 200 adet $S$. Infantis, suşundaki litik spektrumları belirlenerek en geniş spektruma sahip ( $\geq \% 90)$ fajlar seçildi. Bununla birlikte, seçim yapılırken fajların birbirinden farklı olmasını sağlamak için litik profiller de çıkarılmış ve litik profilleri birbirinden farklı fajlar seçilmiştir. Atterbury ve ark. (2007) da benzer olarak faj seçimi yaparken litik spektrumlara ek olarak litik profillere de bakmışlardır. Aynı çalışmada toplam 232 Salmonella fajı izole edilmiş ve farklı serotiplerden oluşan 70 Salmonella suşunda litik spektrum verileri değerlendirilerek 232 fajdan 80 farkl1 $(\% 34,4)$ litik profil bulunmuştur. Cortes ve ark. (2015), 55 adet Salmonella fajının farklı serotiplerden oluşan 67 Salmonella suşunda litik spektrumlarını belirleyerek 39 (\%70) farklı lizis profili elde etmiştir. Bu çalışmada ise litik spektrumuna bakılan 21 fajdan 17 farklı (\%80) litik profil tespit edildi. Bu oran Atterbury ve ark. (2007) ile Cortes ve ark. (2015)'nın buldukları orandan fazladır. Çalışmada tek bir Salmonella serotipine ( $S$. Infantis) ait fajların çalışılması ve fazla sayıda (200 adet) $S$. Infantis suşu üzerinde litik spektrum ve profil belirlenmesi faj çeşitliliğini arttırmıştır.

Moleküler yöntemlerden RAPD-PCR tekniğ $i$ fajların genotipik olarak tiplendirilmesinde ucuz, kolay ve hızlı bir yöntem olması sebebiyle kullanılmaktadır (Gutierrez ve ark. 2011; Cortes ve ark. 2015). Bu sebeple, bu çalıșmada da RAPD-PCR yöntemi, litik profilleri farklı fajlar içinden litik spektrumları geniş $(\geq \% 90)$ olduğu belirlenen toplamda 5 adet $S$. Infantis faj1nın (SF-In7, SF-In18, SF-In20, SF-In35, SF-In37) genotipik olarak tiplendirmesi amacıyla kullanıldı. RAPD-PCR yönteminde farklı primerler kullanılmış ve bu primerlerin ayırım güçleri karşılaştırılmıştır (Gutierrez ve ark. 2011; Cortes ve ark. 2015). Cortes ve ark. (2015) RAPD-PCR'da kullanılan 3 farklı primerden (P1, $\mathrm{P} 2$ ve OPL5), P1 primerinin 34 farkl $\mathrm{PCR}$ paterni ile en yüksek ayrım kapasitesine sahip olduğunu bildirmişlerdir. $\mathrm{Bu}$ sebeple bu çalışmada, yüksek ayırım kapasitesine sahip olmasından dolayı P1 primeri kullanıld1. Cortes ve ark. (2015), 55 adet Salmonella fajının RAPD-PCR'1 sonucu 40 farklı profil elde etmişler ve çıkardıkları litik profillerle kıyasladıklarında RAPD-PCR profilleri ile litik profillerin birbiri ile uyumlu olduğunu bildirmişler- dir. Ancak bu çalıșmada incelenen, litik profilleri farklı $5 \mathrm{~S}$. Infantis fajından 4 farklı RAPD profili elde edildi ve iki fajin (SF-In35, SF-In37) tamamen benzer band sayısına sahip olduğu belirlendi. Fiorentin ve ark. (2004) litik profil ve RAPD band profili uyumsuzluğunun farklı primerler denenerek ortadan kalkabileceğini bildirdiğinden, bu durumun farklı primerler kullanıldığında ortadan kaldırılabileceği düşünüldü.

Faj-bakteri dinamikleri denildiğinde, faj enfeksiyonu için gerekli minimum bakteri ve faj sayıları, fajın konağına adsorbe olma oranı, latent dönem süreleri gibi parametrelerin araştırılması gereklidir (Soykut ve Tunail 2009). Literatürde $S$. Infantis fajlarının faj parametreleri ile ilgili çalışmalara rastlanamamıştır, fakat farklı serotiplere ait Salmonella fajları ve farklı bakteri fajları üzerinde çalışmalar (Wiggins ve Alexander 1985) mevcuttur. Bu çalışmada, seçilen SF-In7 ve SF-In20 fajları ve $S$. Infantis suşu ile yapılan çalışmalar sonucunda faj enfeksiyonu için gerekli minimal $S$. Infantis sayılar1 $7,4 \times 10^{4}-8,2 \times 10^{4} \mathrm{cfu} / \mathrm{ml}$ ve minimal faj sayıları $5,8 \times 10^{4}-6,6 \times 10^{5} \mathrm{pfu} / \mathrm{ml}$ olarak belirlendi.

Salmonella serotiplerine ait fajların adsorbsiyon özelliklerini araştıran yeterince çalışma bulunmamaktadır. Rahaman ve ark. (2014) kümes hayvanlarından izole edilen SAL-PG fajının \%95'inin, $15 \mathrm{dk}$ içinde konak bakterisi $S$. Gallinarum'a adsorbe olabildiğini belirtmişlerdir. Bu çalışmada ise, seçilen SF-In7 ve SF-In20 fajlarının ortalama \%95'inin $20 \mathrm{dk}$ içinde konak hücreye adsorbe olduğu belirlendi. Bu sonucun, Rahaman ve ark. (2014)'nın belirlediği oranla birebir uyumlu olduğu fakat farkl olarak adsorbsiyon süresinin $20 \mathrm{dk}$ olmasının, ö1çümlerin 10 dk'da bir yapılmasından kaynaklandığ kanısına varıldı. Çalışmada seçilen iki fajın yüksek adsorbsiyon oranına sahip olması biyokontrol ajanı olarak kullanılabileceğini düşündürdü. Yapılan çalışmalar incelendiğinde Salmonella fajları da dahil olmak üzere farklı bakteri fajları için farklı latent periyot süreleri mevcuttur (Wiggins ve Alexander 1985; Mirzaei ve Nilsson 2015). Mahmoud ve ark. (2018), 3 adet Salmonella fajnın latent periyotlar1$\mathrm{n} 135 \mathrm{dk}, 40 \mathrm{dk}$ ve $60 \mathrm{dk}$ olarak belirtilmiştir. Bu çalışmada ise seçilen SF-In7 ve SF-In20 fajlarının, konak $S$. Infantis suşu için latent sürelerinin sırasıyla $57 \mathrm{dk}$ ve $65 \mathrm{dk}$ olduğu belirlendi. Bu çalışmada test edilen fajların latent periyot süreleri diğer 
(Wiggins ve Alexander 1985; Mirzaei ve Nilsson 2015) karşılaştırıldığında daha uzundur. Ancak bu çalışma sonuçlarının Salmonella fajları ile yapılan Mahmoud ve ark (2018)'nın çalışmasındaki latent periyod süreleri ile benzerlik göstermesi Salmonella fajlarının daha uzun latent periyod sürelerine sahip olabileceğini düşündürdü.

Literatürde Salmonella fajları ile, Salmonella kolonizasyonunun tavuklarda azaltılması (Atterbury ve ark. 2007; Borie ve ark. 2008; Bardina ve ark. 2012) üzerine ve insanlara Salmonella geçişini azalmak amaciyla gida maddelerinde Salmonella kontaminasyonunun önlenmesi ve azaltılması üzerine birçok çalışma mevcuttur (Spricigo ve ark. 2013; Thung ve ark. 2017; Duc ve ark. 2018). Ancak bulaşma kaynağı olan su, altlık ve yem materyallerinde in-vitro olarak $S$. Infantis fajlarının etkinliğinin araştırıldığı çalışmalar bulunmamaktadır. $\mathrm{Bu}$ çalışmada ise parametreleri belirlenen geniş konak aralığ1 olan SF-In7 ve SF-In20 fajlarının, deneysel olarak $S$. Infantis inoküle edilen su, altlık ve yem numunelerinde Salmonella kontaminasyonunu azaltmadaki etkinlikleri literatürde ilk kez araşt1rildı. Bu çalışmada seçilen iki fajın, 24 saatte, su materyalinde canlı bakteri sayısını yaklaşık olarak $4 \log _{10} \mathrm{cfu} / \mathrm{ml}(\mathrm{p}<0,001)$, altlik materyalinde yaklaşık olarak 2-3 $\log _{10} \mathrm{cfu} / \mathrm{ml}(\mathrm{p}<0,001)$, yem materyalinde ise yaklaşık olarak $3 \log _{10} \mathrm{cfu} / \mathrm{ml}(\mathrm{p}<0,001)$ azalttığı belirlendi. Tüm materyallerde ilk bir saatte sonuç alınamazken, bakteri sayısının azalmasında en iyi etkinlik ilk 12 saatte tespit edilmiş, ancak en iyi sonuçlar 24'üncü saatin sonunda belirlenmiştir. Faj etkinlik bulguları materyal açısından değerlendirildiğinde aynı koşullarda olmalarına rağmen (sabit bakteri sayısı, faj sayısı, sıcaklık, vb.) canlı $S$. Infantis sayısındaki en fazla azalmanın [4 $\log _{10}$ $\mathrm{cfu} / \mathrm{ml}(\mathrm{p}<0,001)]$ su materyalinde gerçekleştiği görüldü. Bunun sebebinin, su materyalinin bakteriyofajların en çok izole edildiği doğal ortamı olması, diğer materyallere kıyasla suda inhibe edici birçok faktörün bulunmaması ve fajların sıvı ortamlarda konak hücre reseptörleri ile buluşmasının daha kolay olacağından, bakterileri infekte etme şanslarının fazla olması ile açıklanabileceği düşünüldü.

Literatürdeki birçok çalışma (Atterbury ve ark. 2007; Borie ve ark. 2008; Bardina ve ark. 2012; Duc ve ark. 2018; Huang ve ark., 2018) incelendiğinde fajlarla yapılan çalışmalarda alınan en temel sonuç, serotip spesifik faj kullanılsa dahi 24 saat sonra ortamdaki Salmonella'ların tamamen giderilememesidir. Bu çalışmada da benzer olarak tüm materyallerde 24 'üncü saatin sonunda, canlı bakteri sayısında yaklaşı $2-4 \log _{10} \mathrm{cfu} / \mathrm{ml}(\mathrm{p}<0,001)$ azalma belirlenmesine rağmen $S$. Infantis'lerin tamamen giderilemediği belirlendi. Bunun en önemli nedeninin, faj-bakteri temasının ilerleyen saatlerinde faj direncinin gelişmesi olabileceği kanısına varıldı. Faj direnci önemli bir sorun teşkil etse de fajların tüm materyallerde bakterilerin sayısını önemli düzeyde azaltması, bakteri dekontaminasyonu için $S$. Infantis fajlarının kullanım potansiyelinin olduğu kanısına varıldı.

Fajların in-vitro yaşam süresini belirlemek için çeşitli çalışmalar yapılmıştır, fakat bu çalışmaların büyük çoğunluğu balık patojenlerinin fajları üzerinedir. Bu çalışmalarda (Nakai ve ark. 1999; Pereira ve ark. 2011; Madsen ve ark. 2013) farklı bakterilere ait fajlara ilişkin farklı yaşam süreleri mevcuttur. $\mathrm{Bu}$ açıdan bakıldığında fajların yaşam sürelerinin konak bakteriye, kullanılan faja ve içinde bulunduğu materyale göre değişiklik gösterdiği söylenebilir. Bu çalışmada, seçilen iki fajın konak hücre bulundurmayan su, yem ve altlik materyallerinde yaşam süresi tespit edildi. Literatür taramalarında $S$. Infantis için su, altlık ve yem materyallerinde yapılan faj yaşam süresi çalışmalarına rastlanamamıştır. Bu sebeple bu çalışma bir ilk olma özelliği taşımaktadır. Bu çalışmada, fajların tüm materyallerde titrelerindeki azalmaya rağmen bir hafta süre canlı kaldığı tespit edildi. Bu bir hafta içerisinde titre bazında başlangıca oranla su materyalinde 2 $\log _{10}$ altlık ve yem materyalinde ise $3,5 \log _{10}$ azalma belirlendi. Yaşam süreleri değerlendirildiğinde ise fajlar su materyalinde 4 hafta, altlık ve yem materyallerinde ise 3 hafta canlılığını korudu. Faj yaşam süresi bulguları materyal açısından değerlendirildiğinde aynı koşullarda olmalarına rağmen en uzun faj yaşam süresi su materyalinde gerçekleştiği görüldü. Bu durumun diğer materyallerle (altlık, yem) kıyaslandığında su materyalinde kurumanın olmamasından, diğer materyallerde ise kuruma meydana geldiği için yüzey geriliminin artması ve buna bağ $1_{1}$ olarak faj titrelerinde düşüş meydana gelmesinden kaynaklandığı düşünüldü. Sonuç olarak çalışmada seçilen iki fajın konak hücre bulundurmayan tüm materyallerde uzun yaşam süresine sahip olması dekontaminasyonda kullanılabileceğini düşündürdü. 
$\mathrm{Bu}$ çalışmada seçilen iki fajın oda $1 \mathrm{~s} 1 \mathrm{~s} 1,4^{\circ} \mathrm{C}$, $-20^{\circ} \mathrm{C}$ ve $-80^{\circ} \mathrm{C}$ 'de saklanma ve kullanılabilirlik süresi literatürde ilk defa araştırıldı. Fajların saklama sürelerine ilişkin çeşitli çalışmalar (Warren ve Hatch, 1969; Zierdt, 1988; Ngangbam ve Devi, 2012; Madsen ve ark., 2013; Bourdin ve ark., 2014) yapılmıştır. Fakat çalışmalarda fajların oda 1sısında saklama süresi ile ilgili verilere rastlanamamıștır. $\mathrm{Bu}$ çalışmada seçilen fajların, oda 1 sında $\left(20-22^{\circ} \mathrm{C}\right)$ 6 hafta süreyle canlılığını koruduğu fakat titrelerinin logaritmik olarak düzenli bir şekilde azaldığ 1 tespit edildi. Koşullar düşünüldügünnde bu sürenin faj çalışmalarında fajları transfer etmek ve saklamak için uygun bir süre olduğu düşünüldü. Warren ve Hatch (1969)'in T3 kolifajının saklama süresini ve stabilitesini inceledikleri çalışmalarında, T3 kolifajının $-20^{\circ} \mathrm{C}^{\prime}$ de dondurularak tutulduğunda nispeten stabil olmasına rağmen, $4^{\circ} \mathrm{C}$ 'de 72 gün boyunca saklandığında, titresinde $2 \log _{10}$ kayıp olduğunu bildirmişlerdir. $\mathrm{Bu}$ çalışmada $4^{\circ} \mathrm{C}$ 'de, ilk 2 ay fajların titrelerinde herhangi bir değişim görülmedi bununla beraber fajlar, titreleri logaritmik olarak azalarak 9 ay süre ile canlılıklarını korudu. $-20^{\circ} \mathrm{C}^{\prime} \mathrm{de}$, ilk 10 ay fajların titrelerinde herhangi bir değişim görülmedi ve toplamda 4 y1l sonunda $8 \log _{10}$ azalarak hala yaşamaya devam etti. Bu bulgular Warren ve Hatch (1969) çalışmalarına benzer olarak fajların dondurulduğunda daha stabil olduğu ve daha uzun süre yaşadığını gösterdi. Ayrıca literatür taramalarında rastlanan Salmonella fajları üzerine tek çalışma olan Ngangbam ve Devi (2012)'nin çalışmalarında da Salmonella fajlar $4^{\circ} \mathrm{C}$ ve $-20^{\circ} \mathrm{C}$ 'de 2 hafta gibi kısa süre saklandığında titrelerinin değişmeden kaldığ 1 belirlenmiştir. Bu bulgular, bu çalışmadaki bulgularla birebir uyum göstermektedir. Bu çalışmada, seçilen fajlar $-80^{\circ} \mathrm{C}$ 'de saklandıklarında ise ilk y1l fajların titrelerinde herhangi bir değişim görülmedi ve toplamda 4 y1l sonunda $6 \log _{10}$ azaldı $\breve{g}_{1}$ fakat hala yaşamaya devam ettiği belirlendi. Ackermann ve ark. (2004), Brucella, Vibrio ve Aeromonas fajlarının $-80^{\circ} \mathrm{C}$ 'de sıv1 nitrojenle tutulduğunda 5 y1la kadar yaşayabileceğini ve 5 yılda bir çoğaltılması gerektiğini bildirmişlerdir. Bu açıdan bakıldığında bu çalışmada $-80^{\circ} \mathrm{C}^{\prime}$ de fajların dördüncü yıl sonundaki ölçümlerde hala yaşamaya devam etmesi bu fajların Ackermann ve ark. (2004)'nın çalışmalarında bildirdikleri verilere benzer olarak 5 yıla kadar yaşayabileceğini düşündürdü. Sonuç olarak çalışmada kullanılan bu iki fajın saklama sürelerinin, dekontaminasyon ve biyokontrol ajanı olarak kullanımlarında transfer ve saklanma için yeterli olduğu kanısina varıldı.

\section{Kaynaklar}

1. Ackermann HW, Tremblay D, Moineau S. (2004) Long-term bacteriophage preservation. World Federation for Culture Collections Newsletter. 38, 35-40.

2. Akhtar M, Viazis S, Diez-Gonzalez S. (2014) Isolation, identification and characterization of lytic, wide host range bacteriophages from waste effluents against Salmonella enterica serovars. Food Control, 38, 67-74.

3. Aksakal A. (2003) Bazı Kanatlıların Dışkılarında Salmonella Türlerinin Varlığ ve Yaygınlığı ile Antibiyotiklere Duyarlılıkları. YYÜ Vet Fak Derg. 14 (1), 95-101.

4. Anonim. (2018) Ulusal Salmonella Kontrol Programı. Erişim adresi: https://tuyekad.org.tr/wp-content/uploads/2018/09/ ULUSAL SALMONELLA KONTROL PROGRAMI pdf Erişim tarihi: 18.10.2019

5. Atterbury RJ, Van Bergen MAP, Ortiz F, Lovell MA, Harris JA, De Boer A, Wagenaar JA, Allen VM, Barrow PA (2007) Bacteriophage Therapy To Reduce Salmonella Colonization Broiler Chickens. Appl Environ Microbio. 73, 4543-4549.

6. Bao H, Zhang H, Wang R. (2011) Isolation and characterization of bacteriophages of Salmonella enterica serovar Pullorum. Poultry Sci. 90, 2370-2377.

7. Bardina C, Spricigo DA, Cortes P, Lagosteraa M. (2012) Significance of the Bacteriophage Treatment Schedule in Reducing Salmonella Colonization of Poultry. Appl Environ Microb. 78(18), 6600-6607.

8. Borie C, Albala I, Sanchez P, Sanchez ML, Ramirez S, Navarro C, Morales MA, Retamales J, Robeson J. (2008) Bacteriophage Treatment Reduces Salmonella Colonization of Infected Chickens. Avian Dis. 52, 64-7.

9. Bourdin G, Schmitt B, Guy LM, Germond JE, Zuber S, Michot L, Reuteler G, Brussow H. (2014. Amplification and Purification of T4-Like Escherichia coli Phages for Phage Therapy: from Laboratory to Pilot Scale. Appl Environ Microbiol. 80(4), 1469-1476.

10. Carey-Smith GV, Billington C, Cornelius AJ, Hudson JA, Heinemann JA. (2006) Isolation and characterization of bacteriophages infecting Salmonella spp. FEMS Microbiol Lett. 258, 182-186.

11. Cortes P, Spricigo DA, Bardina C, Llagostera M. (2015) Remarkable diversity of Salmonella bacteriophages in swine and poultry. FEMS Microbiol Lett. 362, 1-7.

12. Duc HM, Minh SH, Ken-Ichi H, Miyamoto T. (2018) Isolation and application of bacteriophages to reduce Salmonella contamination in raw chicken meat. Food $\mathrm{Scl}$ Tech-Brazil. 91, 353-360.

13. EFSA. (2017) The European Union summary report on trends and sources of zoonoses, zoonotic agents and foodborne outbreaks in 2016. Efsa Journal, 15(12), 5077 
14. EFSA. (2016) The European Union summary report on trends and sources of zoonoses, zoonotic agents and foodborne outbreaks in 2015. Efsa Journal, 14(12),4634

15. Field A. (2009) Discovering Statistics Using SPSS. Third Edition. Dubai: Oriental Press. Chapter 6 p. 166

16. Fiorentin LI, Vieira NDI, Barioni Junior WI, Barros SII. (2004) In vitro characterization and in vivo properties of Salmonellae lytic bacteriophages isolated from free-range layers. Rev Bras Cienc Avic. 6(2), 121-128.

17. Gutierrez D, Martin-Platero AM, Rodriguez A, MartinezBueno M, Garcia P, Martinez B. (2011) Typing of bacteriophages by randomly amplified polymorphic DNA (RAPD) PCR to assess genetic diversity. FEMS Microbiol Lett. 322, 90-97

18. Huang C, Virk SM, Shı J, Zhou Y, Willias SP, Morsy MK, Abdelnabby HE, Liu J, Wang X, Li J. (2018) Isolation, Characterization, and Application of Bacteriophage LPSE1 Against Salmonella enterica in Ready to Eat (RTE) Foods. Front Microbiol, 9: 1046

19. Hyman P, Abedon ST. (2009) Practical Methods for Determining Phage Growth Parameters. Clokie MRJ, Kropinski AM. eds. Bacteriophages Methods and Protocols, Volume 1: Isolation, Characterization, and Interactions. Humana Press, New York. p. 175-202.

20. Kropinski AM, Mazzocco A, Waddell TE, Lingohr E, Johnson PR. (2009) Enumeration of Bacteriophages by Double Agar Overlay Plaque Assay. Clokie MRJ, Kropinski AM. eds. Bacteriophages Methods and Protocols, Volume 1: Isolation, Characterization, and Interactions. Humana Press, New York. p. 69-77.

21. Kutter E. (2009) Phage Host Range and Efficiency of Plating. Clokie MRJ, Kropinski AM. eds. Bacteriophages Methods and Protocols, Volume 1: Isolation, Characterization, and Interactions. Humana Press, New York. p. 141-151.

22. Madsen L. Bertelsen SK, Dalsgaard I, Middelboeb M. (2013) Dispersal and Survival of Flavobacterium psychrophilum Phages In Vivo in Rainbow Trout and In Vitro under Laboratory Conditions: Implications for Their Use in Phage Therapy. Appl Envirol Microbiol. 79(16), 4853 4861.

23. Mahmoud M. Askorab A, Barakata AB, Rabiea OEF, Hassanc ES. (2018) Isolation and characterization of polyvalent bacteriophages infecting multi drug resistant Salmonella serovars isolated from broilers in Egypt. Int $J$ Food Microbiol. 266, 8-13

24. Mirzaei MK, Nilsson AS. (2015) Isolation of Phages for Phage Therapy: A Comparison of Spot Tests and Efficiency of Plating Analyses for Determination of Host Range and Efficacy. PLoS One, 10(3), e0118557.

25. Nakai T, Sugimoto R, Park KH, Matsuoka S, Mori K, Nishioka T, Maruyama K. (1999) Protective effects of bac- teriophage on experimental Lactococcus garvieae infection in yellowtail. Dis Aquat Org. 37(1), 33-41.

26. Ngangbam AK, Devi NB. (2012) Molecular Characterization of Salmonella Bacteriophages Isolated from Natural Environment and its Potential Role in Phage Therapy. Banglad J Microbiol. 29(1), 33-36.

27. Pereira C, Silva YJ, Santos AL, Cunha A, Gomes NC, Almeida A. (2011) Bacteriophages with potential for inactivation of fish pathogenic bacteria: survival, host specificity and effect on bacterial community structure. Mar Drugs. 9(11), 2236-55.

28. Rahaman MT, Rahman M, Rahman MB, Khan MFR, Hossen ML, Parvej MS, Ahmed S. (2014) Poultry Salmonella Specific Bacteriophage Isolation And Characterization. Banglad. J Vet Med. 12(2), 107-114.

29. Sanders ME, Klaenhammer TR. (1980) Restriction and modification in group $\mathrm{N}$ streptococci: effect of heat on development of modified lytic bacteriophage. Appl Environ Microbiol. 40(3), 500-6.

30. Sengül SS, Türkyılmaz S. (2007) Broylerlerde Salmonella Enteritidis ve Salmonella Typhimurium Infeksiyonlarının ELISA ve Drag Sıvap Yöntemleri ile Incelenmesi. J Fac Vet Med Univ Erciyes. 4(2), 85-90.

31. Soykut EA, Tunail N. (2009) Süt Endüstrisinde Sorun Yaratan Termofilik Fajlar. J Food. 34 (2), 107-113.

32. Spricigo DA, Bardina C, Cortes P, Llagostera M. (2013) Use of a bacteriophage cocktail to control Salmonella in food and the food industry. Int J Food Microbiol. 165, 169174.

33. Thung TY, Premarathne JMKJK, Chang WS, Loo YY, Chin YZ, Kuan CH, Tan CW, Basri DF, Radzi CWJWM, Radu S. (2017) Use of a lytic bacteriophage to control Salmonella Enteritidis in retail food. Food Scl Tech-Brazll. 78, 222-225.

34. Warren JC, Hatch MT. (1969) Survival of T3 coliphage in varied extracellular environments. I. Viability of the coliphage during storage and in aerosols. Appl Microbiol. 17(2), 256-61

35. Wiggins AB, Alexander M. (1985) Minimum Bacterial Density for Bacteriophage Replication: Implications for Significance of Bacteriophages in Natural Ecosystems. Appl Environ Microbiol. 49(1), 19-23.

36. Woolston J, Parks AR, Abuladze T, Anderson B, Li M, Carter C, Hanna LF, Heyse S, Charbonneau D, Sulakvelidze A. (2013) Bacteriophages lytic for Salmonella rapidly reduce Salmonella contamination on glass and stainless steel surfaces. Bacteriophage. 3(3), e25697.

37. Zierdt CH. (1988) Stabilities of lyophilized Staphylococcus aureus typing bacteriophages. Appl Environ Microbiol. 54(10), 2590. 